\title{
Sistem Pemantauan Kelayakan Pelumas Oli pada Kendaraan Sepeda Motor dengan Memanfaatkan Teknologi Internet of Things
}

\section{RAMA RAMANDA, OKTAF BRILLIAN KHARISMA, ALEX WENDA, ABDILLAH}

Teknik Elektro, Universitas Islam Negeri Sultan Syarif Kasim Riau, Indonesia Email: ramaramandar@gmail.com

Received 23 April 2021 | Revised 29 Mei 2021 | Accepted 23 Juni 2021

\begin{abstract}
ABSTRAK
Sepeda motor memerlukan perawatan yang oprtimal terutama are mesin yaitu dengan melakukan pergantian oli yang berfungsi sebagai pelumas mesin. Oli mesin membantu menghindari gesekan langsung antara logam di mesin, sehingga mengurangi tingkat kerusakan mesin. Penelitian ini akan dirancang suatu sistem pemantauan pergantian oli sepeda motor berdasarkan jarak tempuh dan waktu pemakaian oli yang berbasis IoT. Dimana penggunaan sepeda motor digunakan untuk menyimulasikan perputaran roda, sensor proximity sebagai pendeteksi putaran roda, serta mikrokontroller ESP32 sebagai pengendali utama, buzzer untuk memperingati pengguna, relay digunakan untuk mematikan mesin sepeda motor, dan GSM sebagai pengirim data. Pada penelitian ini diperoleh hasil yang diharapkan, ketika jarak tempuh mencapai jarak 2000km maka sistem akan memperingati pengguna sepeda motor dan ketika pengguna mengabaikan peringatan tersebut dan jarak mencapai $2100 \mathrm{~km}$ maka sistem mematikan kelistrikan sepeda motor. Namun jika jarak tidak tercapai tetapi pemakaian oli telah mencapai 60 hari maka sistem memperingati pengguna sepeda motor.
\end{abstract}

Kata kunci: Gsm, Mikrokontroler, Otomasi, Sensor, Sepeda Motor

\begin{abstract}
Motorcycles require optimal maintenance, especially the engine, namely by changing the oil, which functions as an engine lubricant. Engine oil helps avoid direct friction between the metals in the engine, thereby reducing engine damage. This research will design a motorcycle oil change monitoring system based on mileage and time of oil usage based on IoT. Where the use of a motorcycle is used to simulate wheel rotation, a proximity sensor is used to detect wheel rotation, as well as the ESP32 microcontroller as the main controller, a buzzer to warn the user, a relay is used to turn off the motorcycle engine, and GSM as a data sender. In this study, the expected results are obtained, where when the distance reaches a distance of $2000 \mathrm{~km}$, the system will warn the motorcycle user and when the user ignores the warning and the distance reaches $2100 \mathrm{~km}$, the system will turn off the motorcycle electricity. However, if the distance is not reached but the oil consumption has reached 60 days, the system will warn motorcycle users.
\end{abstract}

Keywords: Gsm, Microcontroller, Automation, Sensors, Motorcyle. 


\section{PENDAhUlUAN}

Di Indonesia, pada tahun 2018/2019 jumlah kendaraan transportasi berdasarkan data statitik mencapai 146,86 juta unit. Dari angka tersebut (Badan Pusat Statistik, 2019) menunjukkan bahwa sepeda motor adalah paling banyak (81,5 persen) yaitu sebanyak 120,10 juta unit. Sepeda motor merupakan transportasi yang menjadi andalan utama bagi masyarakat Indonesia (Wijayanti, 2017). Pada sepeda motor terdapat sistem yang penting yaitu sistem pelumas. Sistem pelumas sangat berpengaruh terhadap efisiensi dan efektifitas kinerja mesin sepeda motor yang mana setiap mesin kendaraan bermotor memiliki kapasitas dan kuantitas minyak pelumas masing-masing untuk melumasi setiap komponen dalam mesin.

Pergantian oli yang tidak berkala dapat menyebabkan kerusakan pada kinerja mesin, pergantian oli sendiri dapat dilakukan dengan memperhatikan waktu service. Waktu service dapat diketahui dengan mengkonversi putaran roda menjadi jarak tempuh. Umumnya sepeda motor sudah dilengkapi dengan adanya speedometer untuk mengetahui jarak yang ditempuh berbentuk digital, namun sistem yang telah ada masih terdapat kekurangan. Dari survey yang dilakukan didapat data ( 71,4 persen) atau sekitar 39 orang dari 50 dimana pengguna sering kelupaan jarak yang telah ditempuh.

Beberapa penelitian telah dilakukan berkaitan dengan sistem peringatan pergantian oli diantaranya adalah penelitian yang dilakukan (Samsinar et al., 2019) yang berjudul Sistem Peringatan Ganti Oli Berdasarkan Running Hours Mesin, jangka Waktu Pemakaian dan Kekentalan Oli pada Mesin Wire Drawing Berbasis Raspberry Pi, hasil dari pnelitian ini menggunakan 3 parameter yaitu: berdasarkan running hours, jangka waktu pemakaian dan kekentalan oli. $L C D$ dan buzzer sebagai penanda bunyi jika oli sudah harus diganti. Peneilitian selanjutnya yang dilakukan (Iirsyam \& Sadarsyah, 2019) yang berjudul Perancangan Alat Pendeteksi kelayakan Oli Pada Sepeda Motor Berbasis Arduino Uno Atmega328. Penelitian ini menggunakan sensor IgR yang bertujuan mengetahui jenis oli yang menjadi objek penelitian mengambil beberapa sampel oli berdasarkan jarak tempuh kendaraan dan $\angle C D$ digunakan untuk membaca tegangan dari masing-masing jenis oli. Penelitian selanjutnya oleh (Haqiqi et al., 2019) menggunakan sensor water flow dan sensor TCS3200 yang dapat membaca nilai RGB warna oli dan sistem ini membuat otomatisasi yang berguna memeriksa kelayakan oli menggunakan metode naive bayes sebagai klasifikasi kelayakan pelumas oli. Penelitian selanjutnya oleh (Mardiyana \& Suhadi, 2020), yang menggunakan sistem berdasarkan viskositas oli. Dengan memanfaatkan Arduino sebagai mikrokontroler dan LCD sebagai tampilan untuk memonitoring oli sepeda motor sampai ambang batas nilai viskositas. Penelitian selanjutnya yang dilakukan oleh (Attubel et al., 2020) yang menggunakan Arduino, modul GPS, modul GSM, dan modul ACS-712. Jadi setiap kali motor hidup modul ACS-17 mendeteksi adanya arus dari Alternator menandakan mesin sepeda motor hidup, lama mesin sepeda motor hidup diakimulasi sebagai waktu ganti oli.

Terdapat beberapa penelitian yang berkaitan terhadap pemanfaatan sensor proximity diantaranya penelitian yang dillakukan oleh (Abimanyu et al., 2020) dengan judul Perancangan Sistem Monitoring Penggantian Oli Pada Sepeda Motor Berdasarkan Jarak Tempuh. Penelitian ini menggunakan sensor proximity yang bekerja secara induktif. Arduino Uno juga digunakan sebagai sistem pengolahan data, dimana hasil pengolahan data akan ditampilkan berupa peringatan pergantian oli, yang akan menyalakan indikator $L E D$ dan menampilkannya pada $L C D$. 
Dalam sensor proximity tipe E18-D80NK sudah terdapat transmitter dan receiver yang dikemas menjadi satu.

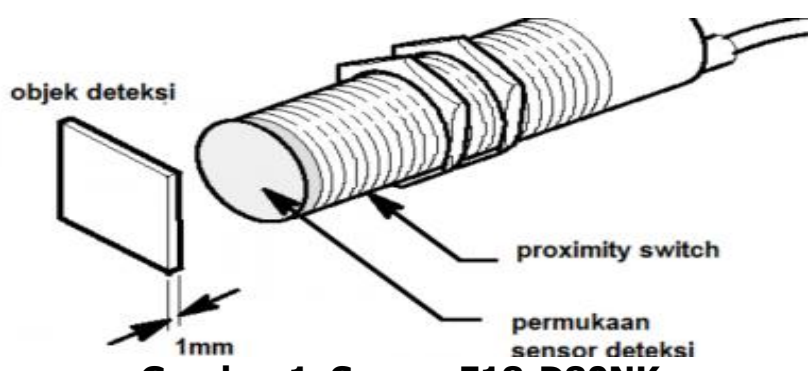

Gambar 1. Sensor E18-D80NK

Sensor ini salah satu jenis modul infrared yang memiliki bentuk yang ringkas dan rapi sensor proximity dapat digunakan untuk membuat otomasi seperti perangkat penghitung, sensor dalam perangkat peringatan sistem alarm keamanan (Paramananda et al., 2018) dan (Laksana et al., 2017). Buzzer digunakan untuk mengubah getaran listrik menjadi getaran suara sebagai penanda (Syams \& Suhartini, 2018). Mikrokontroler ESP32 adalah mikronkontroler SoC (System on Chip) terpadu dengan WiFi $802.11 \mathrm{~b} / \mathrm{g} / \mathrm{n}$, Bluetooth versi 4.2, dan berbagai peripheral, yang menjadi keunggulan dari mikrokontroler ini dibanding dengan yang lain pin out yang lebih banyak, pin analog lebih banyak serta memori yang lebih besar, serta terdapat bluetooth 4.0 low energy (Wagyna \& Rahmat, 2019), (Muliadi et al., 2020). Chip ini menggunakan mikroprosesor 32 bit Xtensa LX6 dual-core. Ruang alamat untuk data dan instruksi adalah 4GB dan ruang alamat periferal $512 \mathrm{kB}$. Kelebihan utama mikrokontroler ini ialah harganya yang relatif murah, mudah diprogram, memiliki jumlah pin I/O yang memadai, serta memiliki adapter WiFi internal untuk mengakses jaringan internet. A6 GSM module dari Ai Thingker Lab yang dapat bekerja pada tegangan $3.3 \mathrm{~V}$ sampai $4.2 \mathrm{~V}$ dengan maksimum power supply sebesar 2 amp (Ali \& Herlangga, 2019) (Putra et al., 2017).

Berdasarkan hasil review yang ada sebelumnya peneliti akan melakukan pengembangan terhadap sistem pengingat yang ada pada sepeda motor. Penliti akan merancang suatu alat yang dapat dipasang pada sepeda motor dengan fungsi utama peringatan awal dan monitoring data jarak tempuh menggunakan mikrokontroler ESP32 dengan sensor proximity dan modul SIM A6 untuk memaksimalkan sistem perawatan pada mesin kendaraan sepeda motor.

\section{METODE PENELITIAN}

\subsection{Perancangan Keseluruhan Sistem}

Penelitian ini diawali dengan langkah-langkah seperti mengumpulkan data-data yang terkait, merancang hardware dan software dan melakukan pengujian. Langkah awal peneliti membuat perancangan blok diagram secara garis besar setiap komponen-kompenen yang terdiri dari sensor proximity, ESP32, A6 GSM module, relay serta buzzer sebagai alarm.

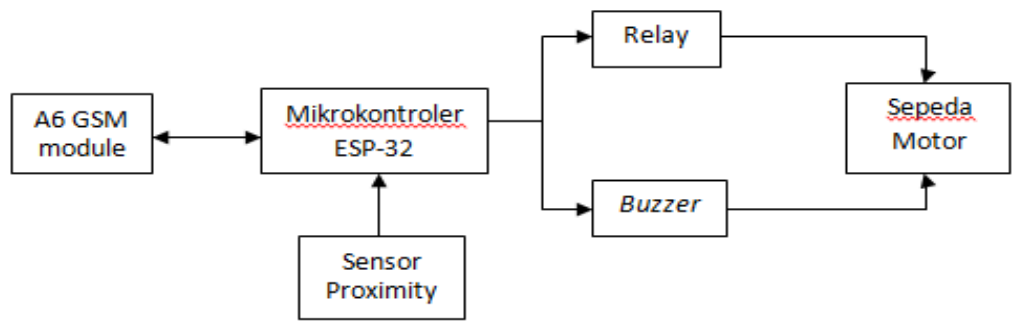

Gambar 2. Blok Diagram Hardware 
Perancangan alat ini menggunakan mikrikontroler ESP32 yang mana sebagai pengontrol sebuah sistem pemantauan kelayakan pelumas oli pada sepeda motor yang terhubung kesemua komponen yang ada pada sistem perancangan ini. Sensor proximity digunakan untuk menghitung rotasi dari roda melalui jari-jari sepeda motor , A6 GSM Module digunakan sebagai membantu dalam pengiriman sinyal atau data pada sistem mikrokontroler, relay disini berfungsi untuk saklar penghubung dan pemutus daya mesin yang ada pada sepeda motor nantinya dan buzzer perangkat audio yang digunakan untuk memperingati pengguna sepeda motor jika pengguna telah melakukan perjalan dengan jarak tempuh parameter yang ditentukan.

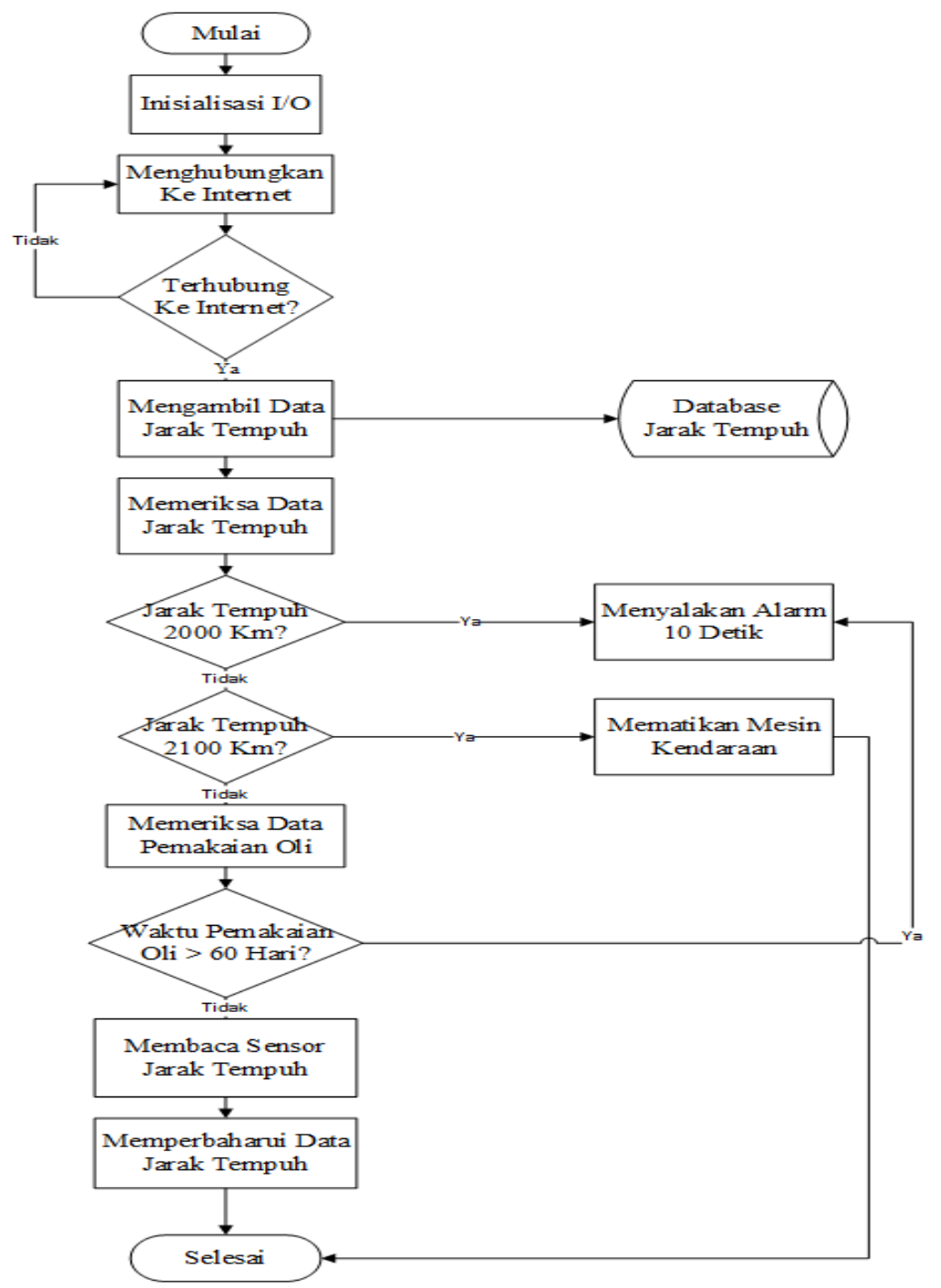

Gambar 3. Diagram Alir Sistem

Flowchart pada listing program yang ditanamkan pada mikrokontroler terdapat pada gambar diatas dengan proses yaitu:

1. Perangkat dimulai akan langsung melakukan inisialisasi pada pin-pin GPIO dengan parameter dan fungsi awal yang telah ditetapkan.

2. Perangkat akan menghubungkan internet untuk menjalankan suatu sistem karna perangkat hanya berjalan hanya jika perangkat terhubung oleh internet.

3. Sensor yang digunakan akan mendeteksi pergerakan dari putaran roda yang mana hasil dari putaran roda tersebut akan terbaca oleh mikrokontroler melalui pengecekan database dari sistem. 
4. Sistem akan memeriksa data jarak tempuh dan membaca jika jarak yang ditempuh telah mencapai parameter $2000 \mathrm{Km}$ maka sistem akan memperingati pengguna sepeda motor dengan menggunakan alarm dari buzzer.

5. Selanjutnya jika pengguna mengabaikan jarak tempuh parameter yang ditetapkan dan jarak telah melewati parameter $2100 \mathrm{Km}$ maka sistem akan otomatisasi memutuskan aliran listrik mesin sepeda motor.

6. Jika jarak tempuh tidak mencapai parameter yang ditetapkan dalam masa kelayakan pemakaian oli maka sistem akan memcbaca waktu pemakaian oli dari masa pergantian oli dan mengingatkan pengguna.

7. Hasil data jarak tempuh dan waktu pemakaian oli akan terkirim otomatisasi pada monitoring pengguna sepeda motor.
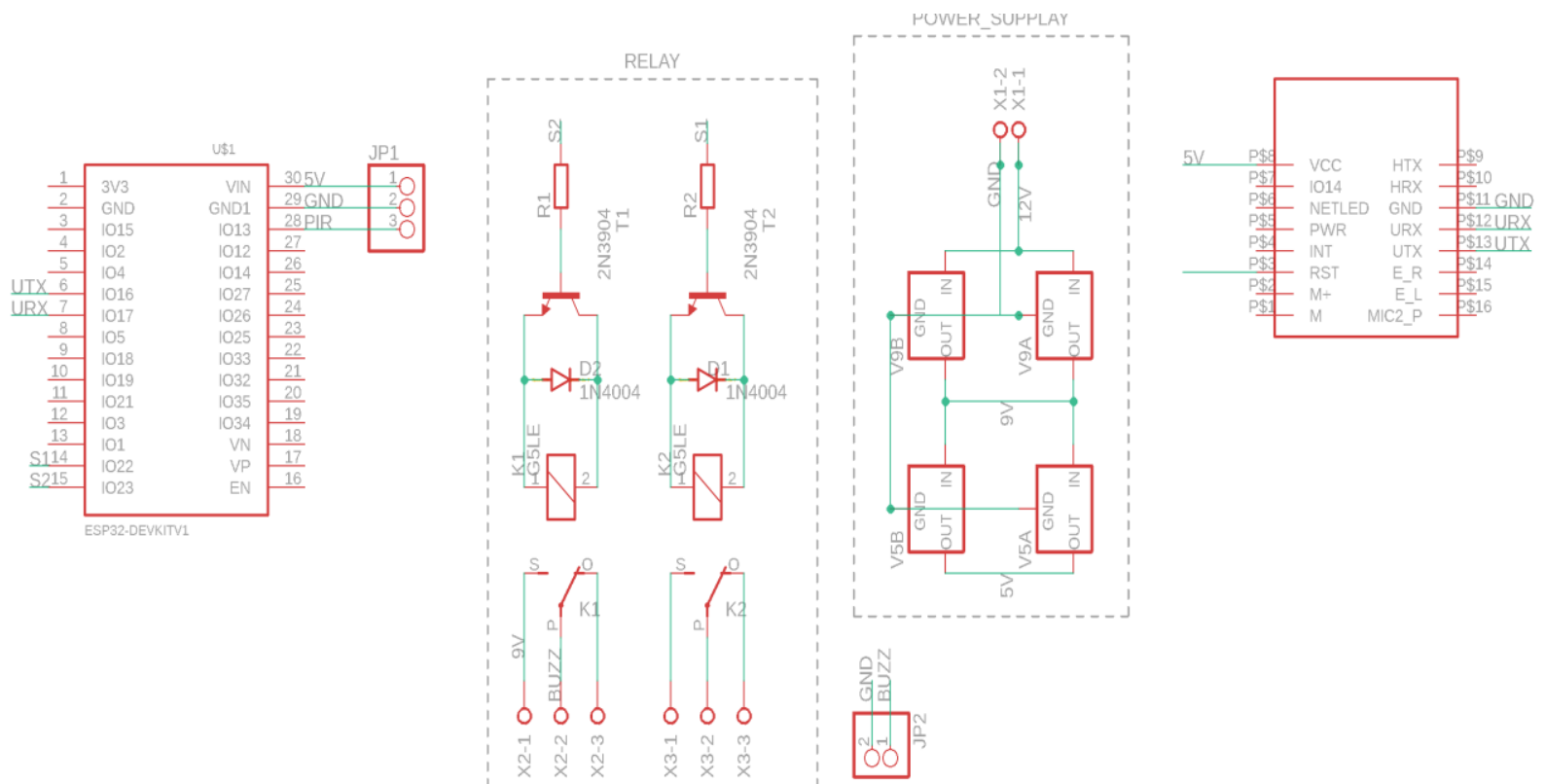

\section{Gambar 4. Sistem Pemantauan Kelayakan Pelumas Oli pada Mesin Kendaraan Sepeda} Motor

Gambar diatas merupakan gambar rangkaian pada sistem pemantauan kelayakan pelumas oli mesin pada kendaraan sepeda motor yang dirangkai melalui aplikasi fritzing yang terdiri dari beberapa komponen seperti mikrokontroler ESP32, modul SimA6, relay, dioda, resistor dan transistor.

\subsection{Perancangan Wiring Pada Sensor Proximtiy}

Perangkat ini menggunakan mikrokontroler ESP32 yang mana sebagai pengontrol sebuah sistem ini. Pada langkah ini perancangan wiring pada sensor proximity yang nantinya digunakan untuk menghitung setiap jari-jari yang melewati sensor akan dihitung dan diakumulasikan menjadi satuan jarak tempuh sepeda motor yang tersimpan pada database sistem. Perancangan ini menghubungkan pin-pin sensor dengan pin ESP32 dapat dilihat pada Gambar 5.

1. Pin Vin ESP32 terhubung dengan kabel Vcc sensor proximity.

2. Pin Gnd pada ESP32 terhubung dengan kabel Gnd sensor proximity

3. Pin D13 pada ESP32 teruhubng dengan kabel signal dari sensor proximity 


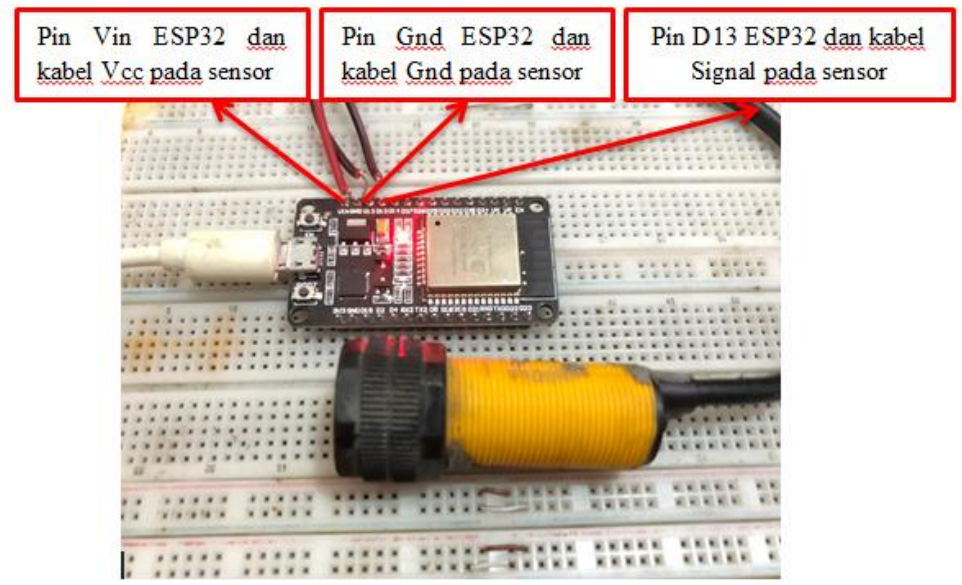

Gambar 5. Rangkaian Wiring pada Sensor

\subsection{Perancangan Wiring Pada Buzzer}

Pada langkah ini perancangan wiring pada buzzer sebagai peringatan awal jika jarak tempuh parameter tercapai maka sistem akan memperingati pengguna sepeda motor melalui buzzer yang berselang selama 10 detik. Pada perancangan ini menghubungkan relay dan buzzer dengan pin ESP32.

1. Pin Vcc pada relay terhubung dengan pin Vin ESP32.

2. Pin Gnd ESP32 terhubung dengan pin Gnd relay dan kabel negatif buzzer.

3. Pin D23 ESP32 terhubung dengan pin In pada relay.

4. Pin COM pada relay terhubung dengan kabel positif buzzer.

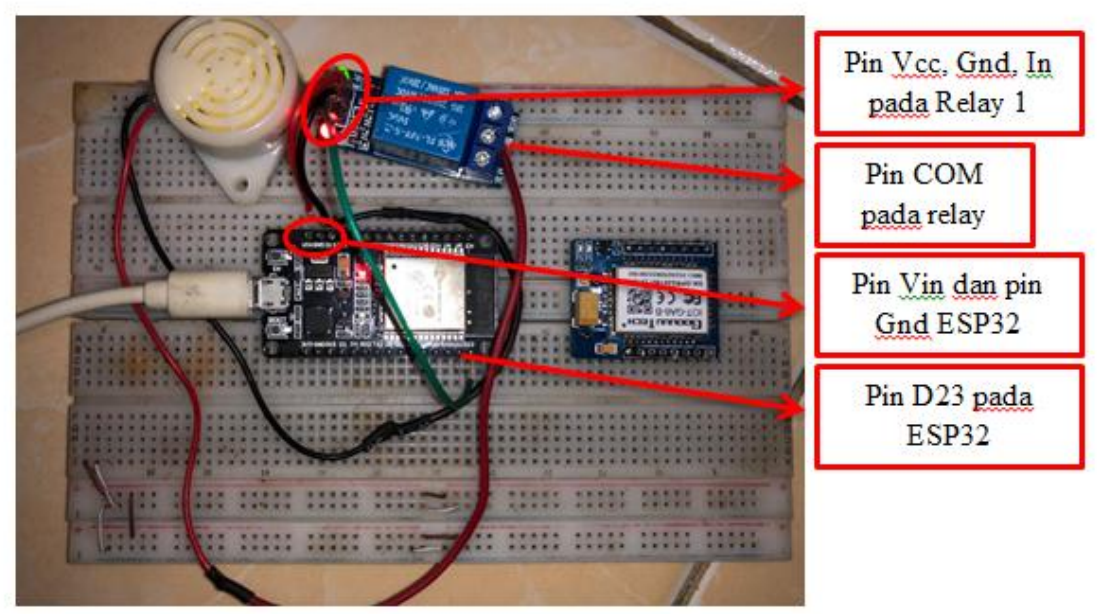

Gambar 6. Rangkaian Wiring pada Buzzer

\subsection{Perancangan Wiring Pada Switch Stand Motor}

Pada langkah ini perancangan wiring pada kelistrikan sepeda motor yang mana berguna bagi pengguna yang mengabaikan peringatan awal untuk melakukan pergantian oli sepeda motor, maka sistem otomatis akan memutuskan aliran listrik sepeda motor melalui relay yang terhubung langsung pada switch stand motor. Perancangan ini menghubungkan pin D22 ESP32 dengan kabel kelistirkan sepeda motor.

1. $\quad$ Pin Vcc dan Gnd pada relay terhubung dengan pin Vin dan Gnd ESP32.

2. Pin D22 pada ESP32 terhubung dengan pin In pada relay .

3. Pin COM dan NC pada relay terhubung dengan kabel sensor switch stand 


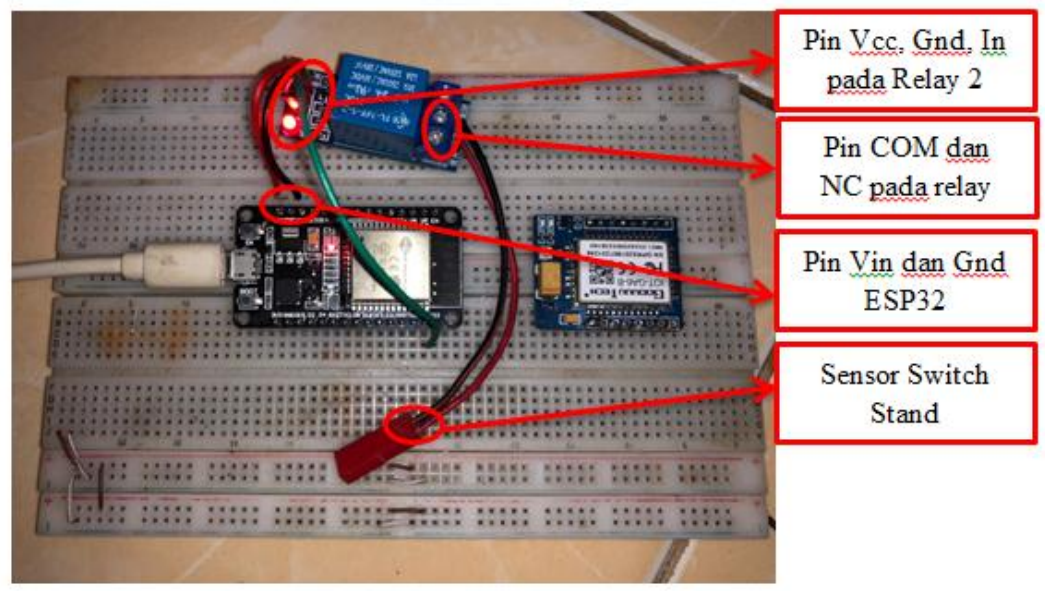

\section{Gambar 7. Rangkaian Wiring pada Kelistrikan Sepeda Motor}

\subsection{Perancangan Wiring Pada Modul Sim A6}

Pada langkah ini perancangan wiring pada modul sim A6 yang berfungsi sebagai pengirim dan penerima data sistem ke database karna ESP32 tidak akan berfungsi atau bekerja jika tidak mendapatkan sinyal, maka diperlukannya modul ini yang terhubung dengan pin ESP32.

1. Pin Vcc pada modul sim A6 yang terhubung dengan pin Vin pada ESP32.

2. Pin Rx pada modul sim A6 terhubung dengan pin Rx pada ESP32.

3. Pin Tx pada modul sim A6 terhubung dengan pin Tx pada ESP32.

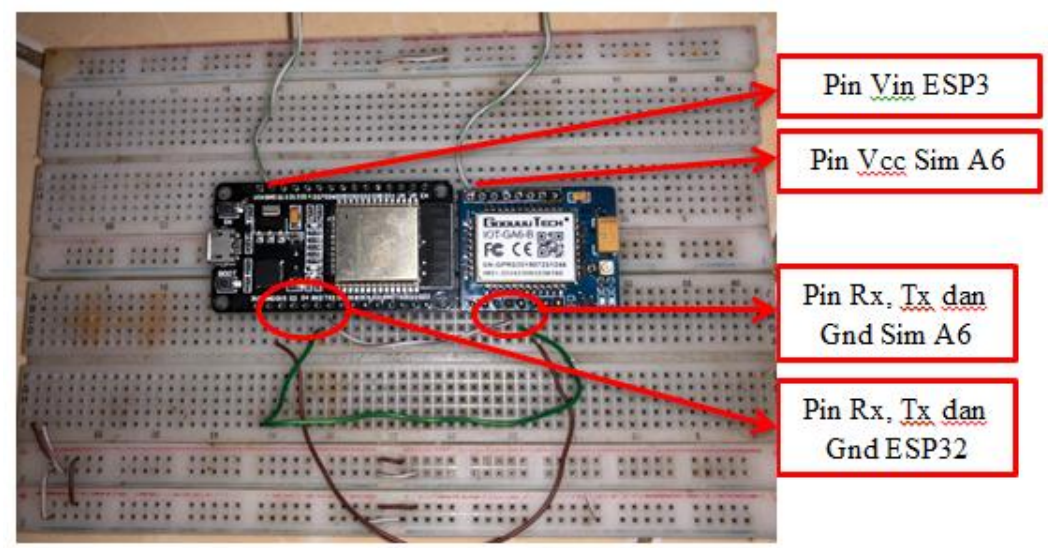

Gambar 8. Rangkaian Wiring pada Sim A6

\subsection{Rumus Perhitungan Keliling Ban}

Pada langkah ini dilakukan perhitungan keliling ban dimana ini berguna untuk mendapatkan hasil perhitungan jarak yang akan ditempuh.

\begin{tabular}{|l|r|r|}
\hline \multicolumn{3}{|c|}{ Rumus Keliling Ban } \\
\hline \multirow{2}{*}{ Ban Luar } & $80 \mathrm{~mm}$ & $8 \mathrm{~cm}$ \\
\cline { 2 - 3 } & $90 \mathrm{~mm}$ & $9 \mathrm{~cm}$ \\
\hline Velg & 14 inch & $35,56 \mathrm{~cm}$ \\
\hline Keliling & \multicolumn{2}{|c}{$162 \mathrm{~cm}$} \\
\hline
\end{tabular}

Gambar 9. Perhitungan Keliling Lingkaran Ban 
Disini pengguna menggunakan ban yang berukuran $80 / 90 \mathrm{~mm}$ dimana tinggi dari ban $80 \mathrm{~mm}$ dan lebar ban $90 \mathrm{~mm}$ sedangkan velg yang digunakan velg uk uran 14inch.

$$
\begin{aligned}
& T=\frac{80}{10}=8 \mathrm{~cm} \quad L=90 / 10=9 \mathrm{~cm} \\
& d=14 * 2.54=35.56 \\
& \text { keliling }=(35.56+(2 * 8)) * \frac{22}{7} \\
& =162 \mathrm{~cm}
\end{aligned}
$$

Jadi, keliling dari ban yang pengguna gunakan yaitu $162 \mathrm{~cm}$.

Ket: T: Tinggi

L:Lebar

d:Diameter

\subsection{Rumus Perhitungan Per Counter}

Pada langkah ini dilakukan perhitungan counter data dari sensor proximity yang digunakan.

\begin{tabular}{|l|r|}
\hline \multicolumn{2}{|l|}{ Rumus menentukan Counter } \\
\hline Keliling Ban & $162 \mathrm{~cm}$ \\
\hline Jumlah Spoke & 5 \\
\hline Counter/O.5 KM & 1543 \\
\hline Counter/KM & 3086 \\
\hline
\end{tabular}

Gambar 10. Perhitungan Counter

Pada langkah sebelumnya terdapat keliling ban yang digunakan $162 \mathrm{~cm}$ dan untuk jumlah spoke pada velg ada 5 spoke. Pengguna menginginkan data yang ter-update sekitar $500 \mathrm{~m}$ $(50000 \mathrm{~cm})$ untuk sekali update.

Update per $500 \mathrm{~m}$ :

$$
D=50000 /\left(\frac{162}{5}\right)=1543
$$

Update per kilometer :

$$
D=100000 /\left(\frac{162}{5}\right)=3086
$$

\subsection{Sistem Perhitungan Jarak}

Tabel 1. Sistem Perhitungan Jarak

\begin{tabular}{|c|c|c|c|}
\hline $\mathbf{M}$ & $\mathbf{K M}$ & Counter & Ket \\
\hline 500 & 0.5 & 1613 & Aman \\
1000 & 1 & 3086 & Aman \\
10000 & 10 & 32258 & Aman \\
100000 & 100 & 322581 & Aman \\
1000000 & 1000 & 3225806 & Aman \\
2000000 & 2000 & 6451613 & Peringatan Pergantian Oli \\
\hline 2100000 & 2100 & 6774194 & Mematikan Mesin Sepeda Motor \\
\hline
\end{tabular}


Tabel diatas merupakan perhitungan jarak yang mana jika jarak kendaraan sepeda motor mencapai jarak yang dianjurkan untuk melakukan pergantian oli maka sistem akan memperingati pengguna sepeda motor selama kendaraan motor dihidupkan, dan jika pengguna mengabaikan peringatan tersebut maka sistem akan mematikan mesin kendaraan, jika hal ini diabaikan maka sistem akan mematikan mesin kedaraan setiap kali kendaraan dihidupkan.

\section{HASIL DAN PEMBAHASAN}

Setelah selesai dirancang pada setiap komponen langkah selanjutnya melakukan parameter kerja sistem. Pembahasan bagian ini meliputi perancangan hardware dan software sehingga mendapatkan data hasil penelitian ini.

\subsection{Implementasi Hasil Rancangan Hardware}

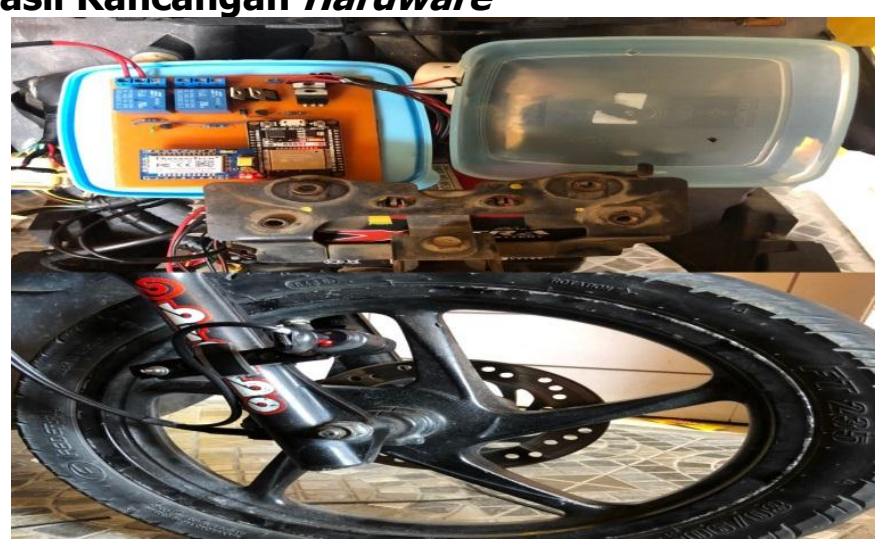

Gambar 11. Perancangan Hardware Secara Keseluruhan

Sistem ini dirancang sedemikian rupa yang mana komponen mikrokontroler ESP32 sangat berfungsi sebagai pengendali sistem yang saling terhubung dengan buzzer, sim A6, dan relay yang terletak didalam body depan sepeda motor. Sistem ini menggunakan tegangan dari accu sepeda motor $12 \mathrm{v}$ dikurangi menjadi $5 \mathrm{v}$ dengan menggunakan transistor pnp L7805V yang mana keluarannya langsung terhubung pada ESP32 dan sim a6. Serta ada 2 relay sebagai saklar yang nantinya jika jarak yang ditempuh mencapai $2000 \mathrm{~km}$ maka saklar pertama akan memperingati melalui buzzer dan jika jarak yang ditempuh mencapai $2100 \mathrm{~km}$ maka relay kedua akan menonaktifkan atau memutuskan arus listrik yang ada pada sepeda motor. Sedangkan sensor proximity dipasang pada shock breker menghadap ke spoke roda yang akan dihitung setiap melawati sensor, hasil dari perhitungan ini nantinya diakumulasikan menjadi jarak tempuh sehingga meningkatkan keamanan pada sepeda motor saat berkendara.

\subsection{Implementasi Aplikasi Web}

Hasil tampilan dari web dapat dilihat pada Gambar 12. Dimana saat pengguna ingin memonitoring hasil jarak yang telah ditempuh pengguna diharuskan melakukan login terlebih dahulu jika pengguna belum mempunyai akun maka pengguna diharuskan untuk mendaftar menggunakan email aktif, hal ini dilakukan untuk meningkatkan keamanan pada sisi perangkat lunak. 


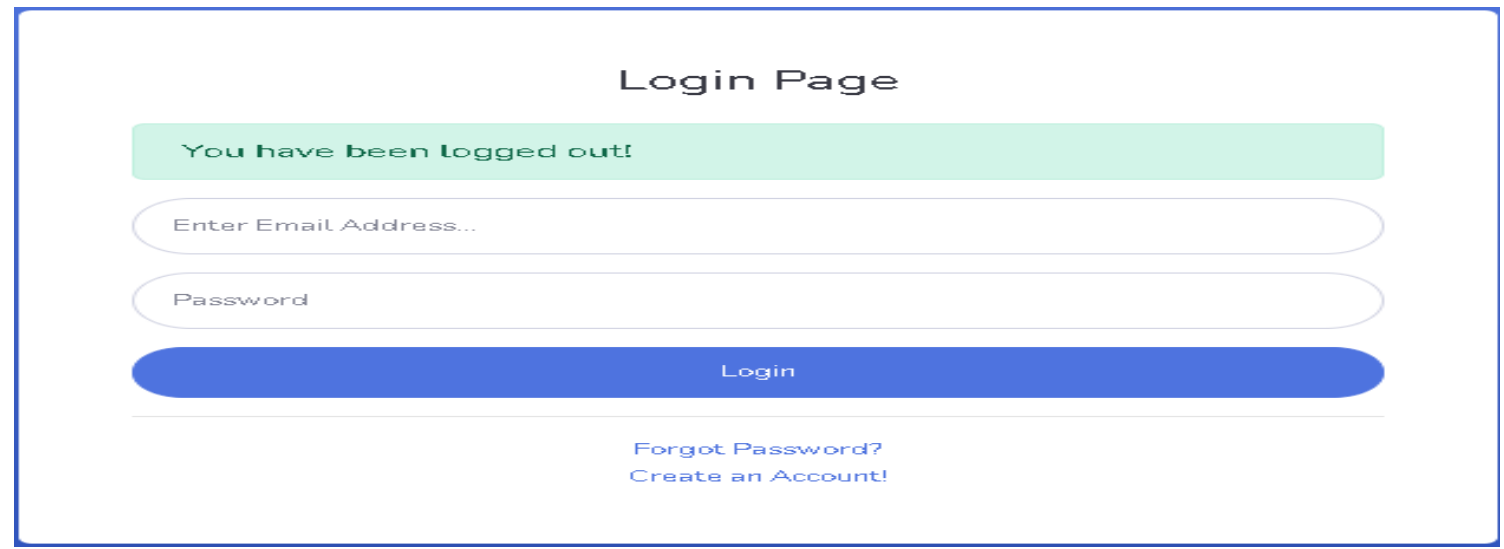

Gambar 12. Login Page

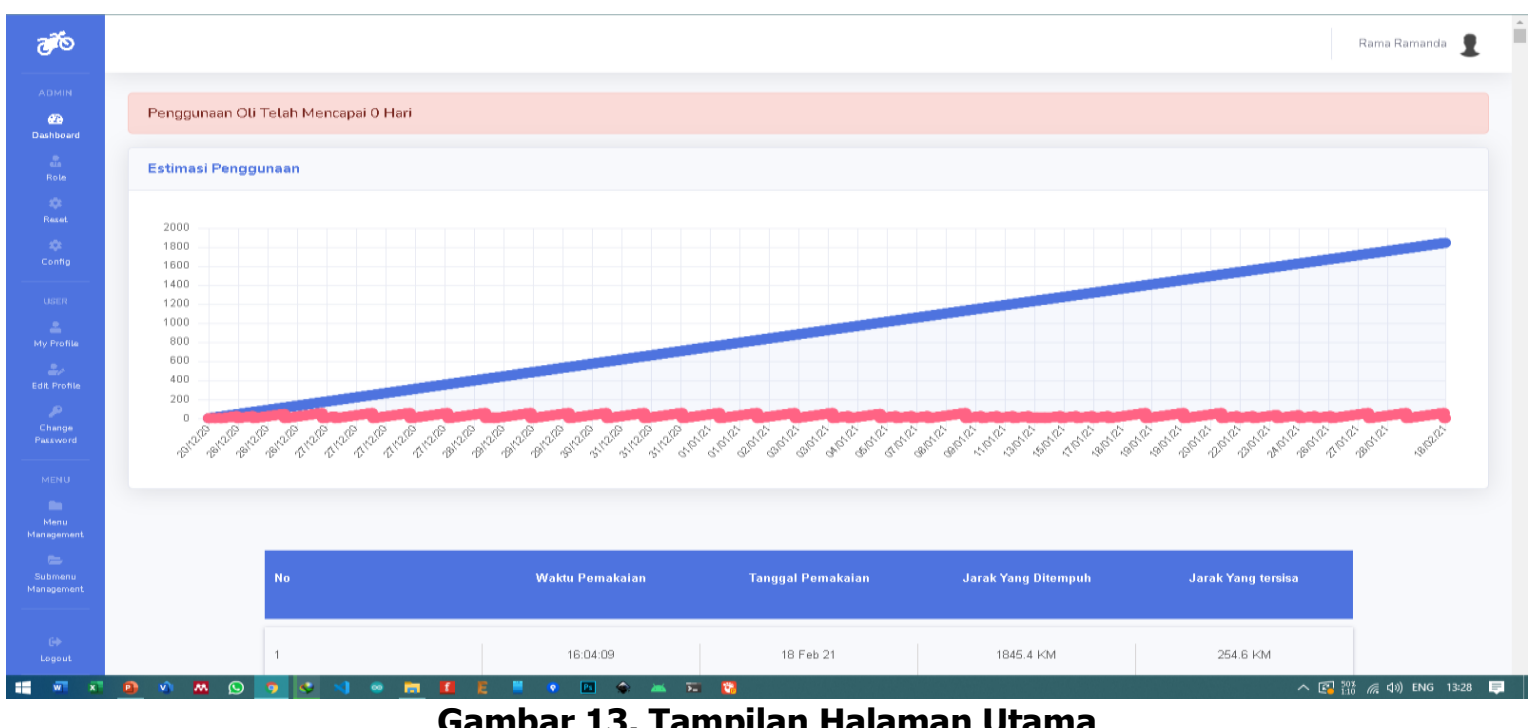

Gambar 13. Tampilan Halaman Utama

Pada halaman utama akan menampilkan grafik jarak harian maupun jarak tempuh total serta data jarak tempuh pemakaian sepeda motor, sehingga pengguna sepeda motor dapat memonitoring dan memantau setiap saat waktu service untuk melakukan pergantian oli pada sepeda motornya. Pada halaman utama juga terdapat fitur-fitur seperti fitur reset, profil, logout, dan fitur configuration.

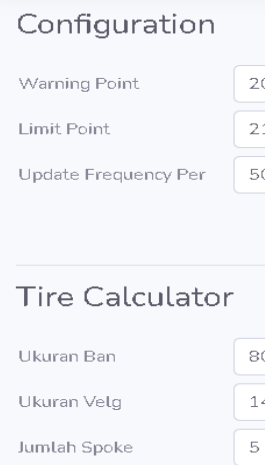

\section{Gambar 14. Fitur Configuration}

Pada fitur ini berguna untuk melakukan update pada sistem yang terdiri dari warning point yang berguna untuk setiap jarak jempuh yang dicapai maka sistem akan memperingati pengguna, sert limit point berguna jika jarak yang ditentukan telah tercapai maka sistem akan 
memutuskan kelistrikan sepeda motor dan ada update frequency yang mencatat setiap 500m perjalanan pada dashboard tampilan utama.

Tier calculator berguna untuk menghitung ukuran velg dan ban sepeda motor karna ukuran ban dan velg yang berbeda akan mempengaruhi jarak yang ditempuh sepeda motor.

\subsection{Pengujian Jarak Tempuh Berdasarkan Goggle Maps}

Pengujian ini dilakukan dengan mengambil data perbandingan antara data jarak yang ditempuh menggunakan sensor proximity dengan data yang terdapat pada goggle maps. Pada pengujian ini dilkakukan dengan menentukan titik acuan pada goggle maps. Titik acuan dapat dilihat pada Gambar 15.

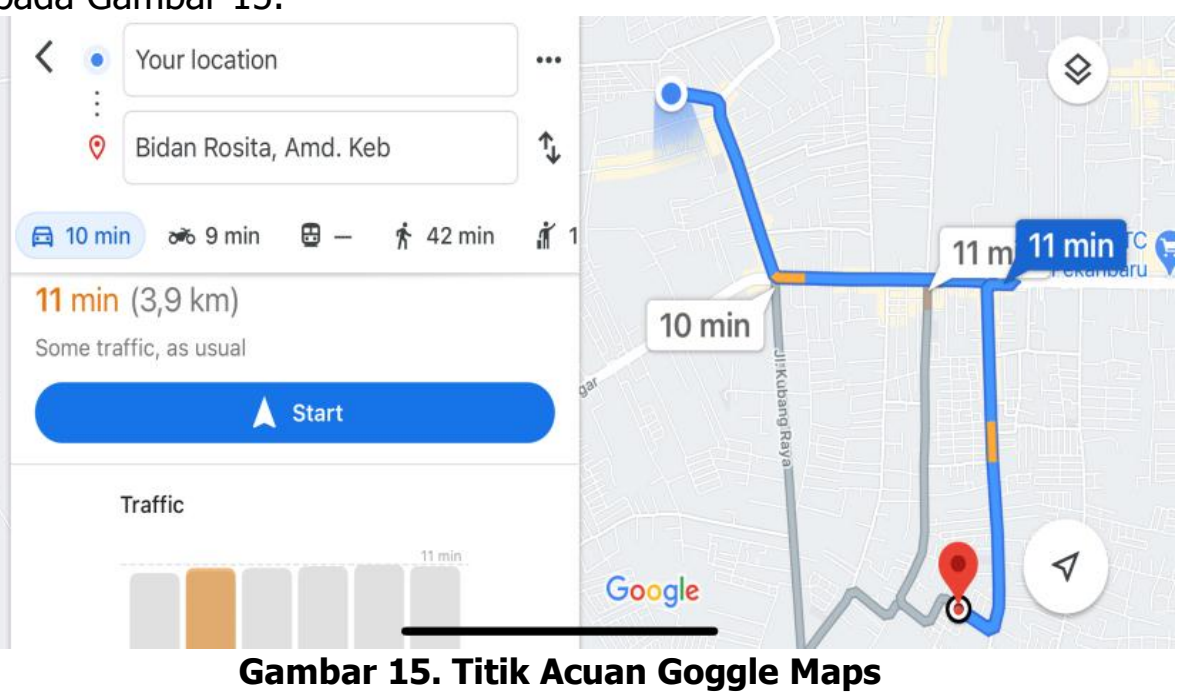

Dari Gambar 15 titik acuan yang telah ditentukan dari lokasi pertama menuju ke lokasi kedua terdapat jarak yang ditempuh sekitar $3.9 \mathrm{~km}$ yang mana memakan waktu sekitar 11 menit tergantung kecepatan dan padatnya jalanan. Data yang didapat dari alat atau sensor proximity yang telah diakumulasikan yaitu sekitar $3.5 \mathrm{~km}$ yang mana data dari titik acuan pertama $2 \mathrm{~km}$ ke titik acuan kedua 5,5 $\mathrm{Km}$ yang berselisih $0.40 \mathrm{~km}$ dengan goggle maps dapat dilihat pada Gambar 16.

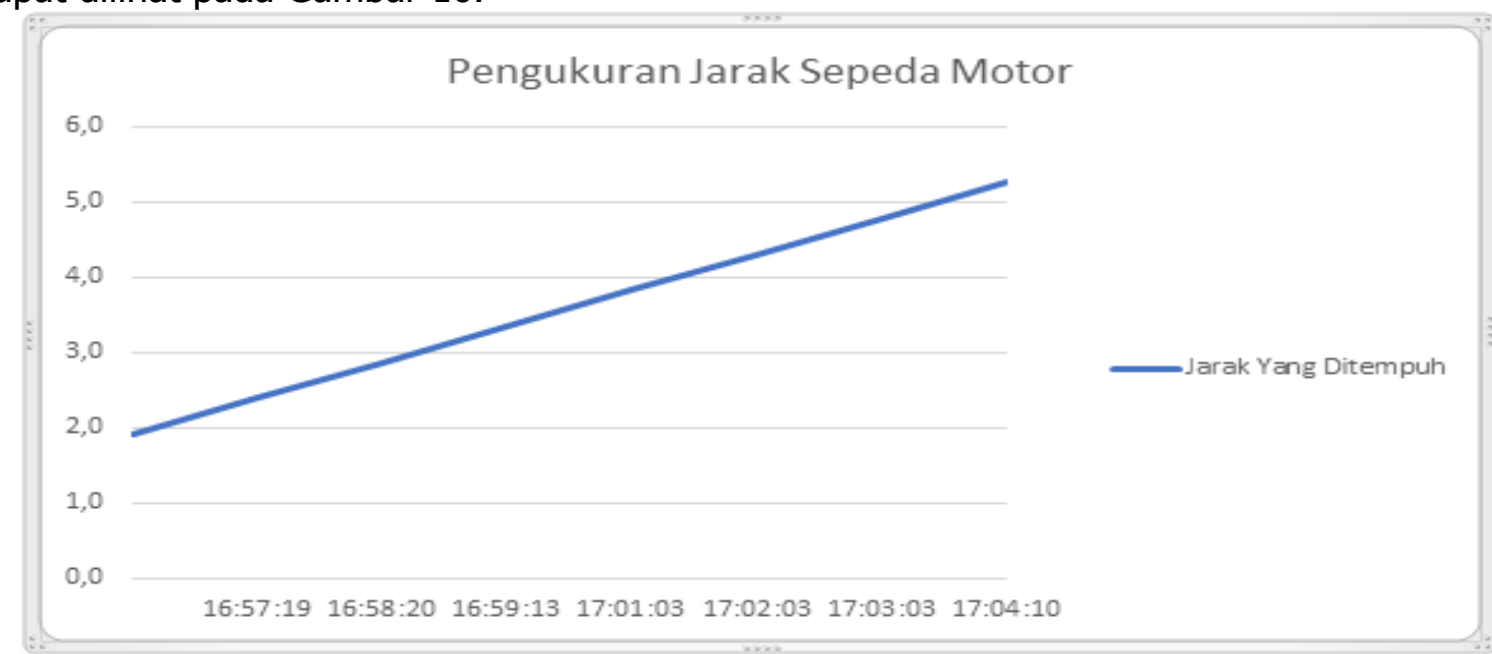

Gambar 16. Data Jarak Tempuh pada Web

\subsection{Sistem Peringatan Pergantian Oli Pada Sepeda Motor}

Pengujian ini dilakukan dengan mengambil data dari jarak tempuh total sepeda motor yang telah terpasang dengan alat ini seperti pada Gambar 17. 


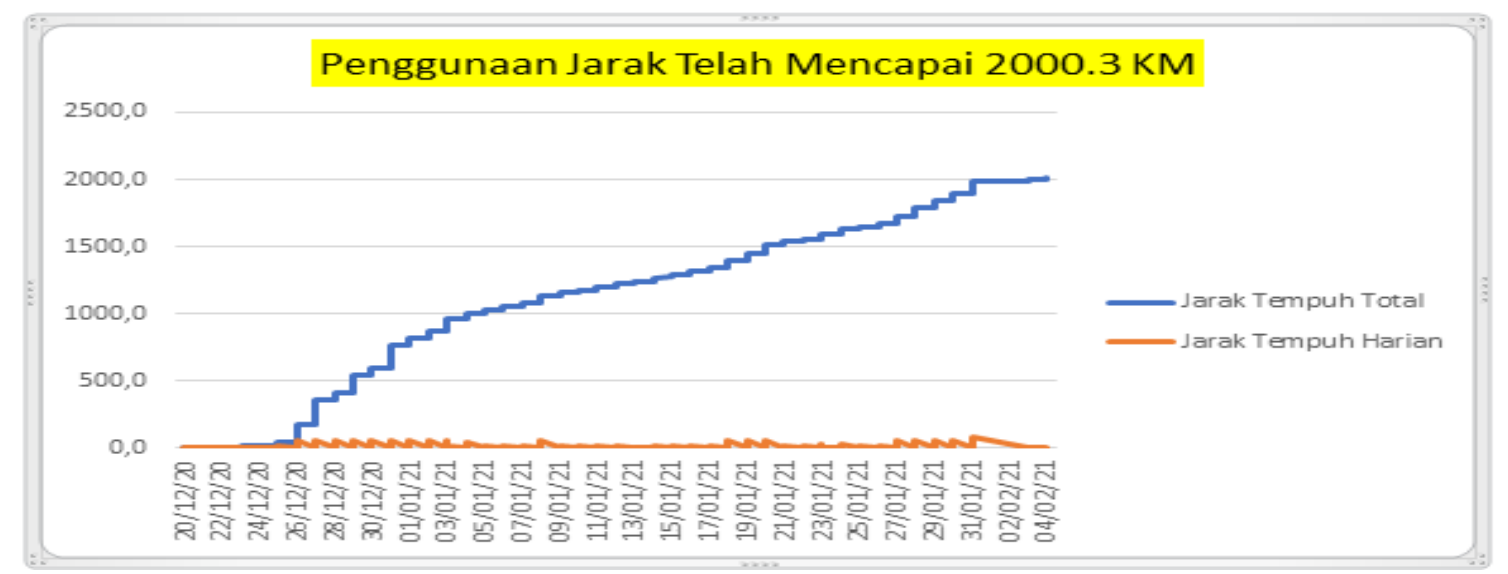

Gambar 17. Grafik Peringatan Jarak Tempuh

Gambar 17 menampilkan hasil dari jarak tempuh sepeda motor yang mana telah mencapai $2000.3 \mathrm{~km}$ alat ini mencatat data jarak dengan baik dan sistem dijarak tempuh ini memperingati pengguna sepeda motor untuk melakukan pergantian oli melalui buzzer yang terpasang pada sepeda motor. Pengguna akan diperingati setiap kali menghidupkan sepeda motor berselang selama 10 detik jika pengguna mengabaikan maka peringatan ini akan terus berulang sampai pengguna melakukan pergantian oli. Hal ini diterapkan sangat berguna bagi pengguna sepeda motor yang lupa dengan jarak tempuh yang seharusnya melakukan pergantian oli karna dengan kekuatan bunyi 80-85 dB dari buzzer dapat menganggu kenyamanan pengguna sehingga pengguna dapat memonitoring jarak tempuh dan melakukan pergantian oli secepatnya.

\subsection{Pengujian Sistem Mematikan Mesin Sepeda Motor}

Pengujian ini dilakukan dengan mengambil data dari jarak tempuh total pada sepeda motor yang telah terpasang alat seperti pada Gambar 18.

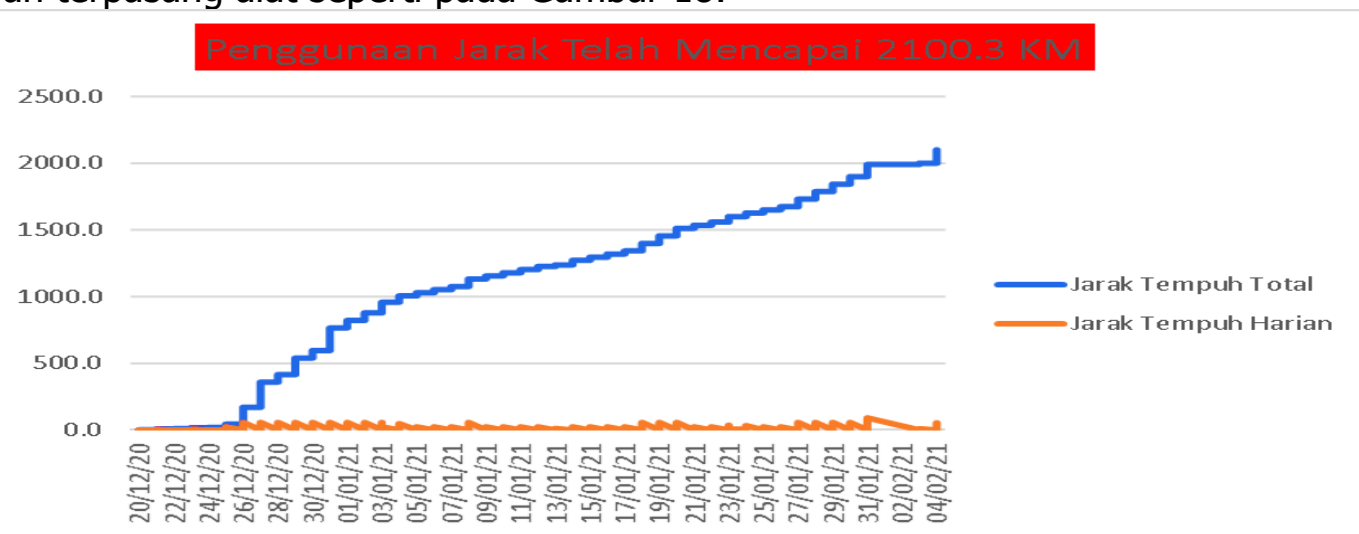

Gambar 18. Grafik Pengukuran Jarak Tempuh Mematikan Mesin Sepeda Motor

Gambar 18 menampilkan data jarak tempuh telah mencapai jarak maksimal yaitu $2100 \mathrm{~km}$ dimana seperti yang disarankan untuk melakukan pergantian oli sepeda motor pada jarak $2000 \mathrm{~km}$, jika dijarak $2100 \mathrm{~km}$ pengguna dalam keadaan berkendara maka sistem akan memperingati pengguna melakukan pergantian oli pada sepeda motor dengan bunyi yang melalui buzzer berselang selama 10 detik jika pengguna tetap mengabaikan peringatan ini maka sistem akan otomatis mematikan mesin kendaraan sepeda motor yang terhubung pada switch stand karna sebelumnya pengguna sudah diperingati terlebih dahulu namun pengguna mengabaikan peringatan dari sistem. Dan disaat pengguna tetap menghidupkan sepeda motor maka sistem akan memperingati pengguna sepeda motor kembali melalui buzzer dan akan mematikan kelistrikan sepeda motor lagi seperti yang terjadi sebelumnya. 


\subsection{Sistem Peringatan Masa Penggunaan Pelumas Oli}

Sistem ini berfungsi memperingati pengguna sepeda motor untuk melakukan pergantian oli, hal ini terjadi jika masa pemakaian oli lebih mencapai dahulu daripada jarak yang telah ditempuh pengguna, peringatan yang dilakukan sistem dengan memperingati pengguna melalui buzzer, karna dari survey yang telah dilakukan masa pemakaian oli baik kendaraan digunakan ataupun tidak kelayakan pada pelumas oli itu baiknya kurang lebih 60 hari.

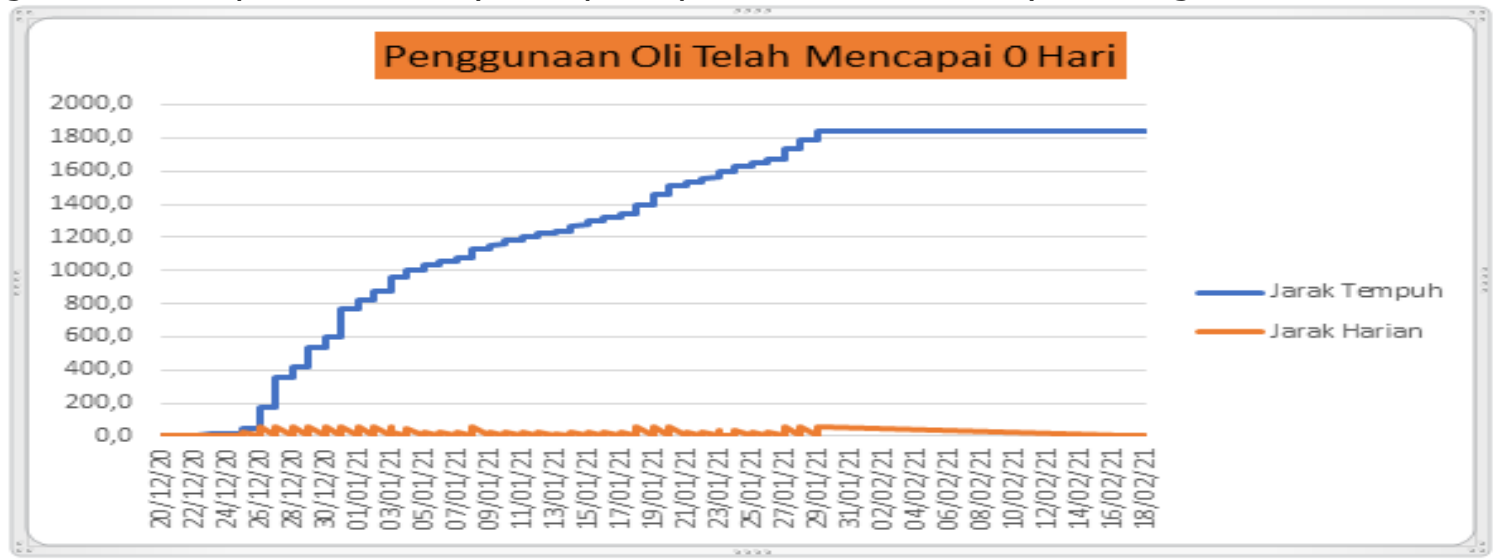

Gambar 19. Grafik Pengukuran Masa Penggunaan Pelumas Oli

\subsection{Uji Respon Time Update Data}

Pengujian ini dilakukan menggunakan sepeda motor dengan jaringan data yang terdapat pada modul sim A6 yang terpasang pada alat rancangan ini dengan kecepatan kendaraan rata-rata 40-60 km/jam melalui aplikasi program Arduino selama pengguna melakukan perjalanan, dapat dilihat pada tabel berikut:

Tabel 2. Pengujian Respon Time Update Data

\begin{tabular}{|c|c|c|c|}
\hline Percobaan & $\begin{array}{c}\text { Kirim } \\
\text { Data }\end{array}$ & $\begin{array}{c}\text { Terima } \\
\text { Data (s) }\end{array}$ & $\begin{array}{c}\text { Total } \\
(\mathbf{s})\end{array}$ \\
\hline 1 & 2.11 & 1.46 & 3.56 \\
\hline 2 & 0.42 & 1.59 & 2.01. \\
\hline 3 & 1.55 & 1.92 & 3.47 \\
\hline 4 & 0.61 & 1.83 & 2.44 \\
\hline 5 & 2.30 & 1.82 & 4.13 \\
\hline 6 & 1.87 & 3.19 & 5.06 \\
\hline 7 & 0.19 & 1.83 & 2.02 \\
\hline 8 & 0.37 & 1.83 & 2.20 \\
\hline 9 & 0.23 & 1.69 & 1.92 \\
\hline 10 & 0.28 & 1.83 & 2.11 \\
\hline Rata-rata & $\mathbf{0 . 9 9}$ & $\mathbf{1 . 9 0}$ & $\mathbf{2 . 8 9}$ \\
\hline
\end{tabular}

Tabel diatas merupakan hasil data dari uji coba respon time dengan per 10 kali update data yang diupdate sekitar $500 \mathrm{~m}$ setiap pengguna melakukan perjalanan. Dimana data yang 
dikirim memakan waktu rata-rata 0.99/s, sedangkan data yang diterima oleh sistem sekitar $1.90 / \mathrm{s}$ jadi total data untuk sekali update perkiraan waktu mencapai $2.89 / \mathrm{s}$.

\section{KESIMPULAN}

Kesimpulan yang dapat diambil pada penelitian ini antara lain :

a. Perancangan alat ini secara keseluruhan berfungsi dengan baik, dari segi hardware ataupun software melingkupi dalam proses pengujian,pengukuran, peringatan, penyimpanan, pengaturan data serta komunikasi akuisisi data.

b. Hasil pengujian pembacaan sensor jarak berhasil digunakan untuk menunjukkan status jarak tempuh dengan persentase perbandingan $0.5 \%$ dengan kecepatan rata-rata $40-60$ $\mathrm{km}$

c. Dengan menggunakan ESP32 dan modul sim A6 perubahan data jarak tempuh dan masa penggunaan pelumas oli dapat direfleksikan kepada pengguna secara real time.

d. Alat ini dapat diaplikasikan pada semua jenis sepeda motor matic yang menggunakan velg racing atau velg bawaan.

Namun alat ini masih terdapat beberapa kekurangan. Adapun saran untuk pengembangan berikutnya dari sistem ini yaitu penambahan GPS untuk melengkapi keberadaan sepeda motor. Kemudian penggunaan sensor yang lebih terbaru untuk diaplikasikan ke semua sepeda motor yang menggunakan velg racing dan velg jari-jari.

\section{DAFTAR PUSTAKA}

Abimanyu, K., Lestari, N., Fauzi, M. A., \& Nurcahya, A. (2020). Perancangan Sistem Monitoring Penggantian Oli Pada. 13(1), 58-70.

Ali, B., \& Herlangga, H. (2019). Rancang Bangun Prototype Thief Detector dengan SMS Gateway Berbasis Atmega 2560. 134-142.

Attubel, M., Siswanto, D., \& Mukshim, M. (2020). Sistem Pemantauan Dan Pengingat Waktu Perawatan Kendaraan Berbasis Internet of Things (Iot). JASEE Journal of Application and Science on Electrical Engineering, 1(01), 51-65. https://doi.org/10.31328/jasee.v1i01.6

Badan Pusat Statistik. (2019). Perkembangan Jumlah Kendaraan Bermotor Menurut Jenis. In Badan Pusat Statistik (pp. 1-4). http://bps.go.id/linkTableDinamis/view/id/1133

Haqiqi, M. F., Syauqy, D., \& Arwani, I. (2019). Sistem Pengecek Kelayakan Pakai Oli Motor Matic Berdasarkan Parameter Warna dan Viskositas Menggunakan Metode Bayes. Jurnal Pengembangan Teknologi Informasi Dan Ilmu Komputer, 3(4), 4048-4057.

Iirsyam, M., \& Sadarsyah, P. (2019). Perancangan Alat Pendeteksi Kelayakan Oli Pada Kendaraan Sepeda Motor Berbasis Arduino Uno Atmega328. Sigma Teknika, 2(2), 179. https://doi.org/10.33373/sigma.v2i2.2061

Laksana, B. A., Rasmana, S. T., \& Triwidyastuti, Y. (2017). Journal of Control and Network Systems. JCONES Journal of Control and Network Systems, 3(2), 9-17.

Mardiyana, D., \& Suhadi, A. (2020). Peringatan Ganti Oli Pada Sepeda Motor. 10(1), 41-46. 
Muliadi, Imran, A., \& Rasul, M. (2020). Pengembangan tempat sampah pintar menggunakan esp32. Media Elektrik, 17(2), 1907-1728.

Paramananda, R. G., Fitriyah, H., \& Prasetio, B. H. (2018). Rancang Bangun Sistem Penghitung Jumlah Orang Melewati Pintu menggunakan Sensor Infrared dan Klasifikasi Bayes. Jurnal Pengembangan Teknologi Informasi Dan IImu Komputer (J-PTIIK) Universitas Brawijaya, 1(3), 921-929.

Putra, G. E. W., Suniantara, K. P., \& Kumara, S. (2017). Implementasi dan Analisis Perangkat Pengirim Data Sensor melalui Modul A6 GSM/GPRS berbasis Microcontroller. 7. https://doi.org/10.31219/osf.io/n7bwc

Samsinar, R., Almanda, D., \& Priatna, E. (2019). Sistem Pengingat Ganti Oli Berdasarkan Running Hours Mesin, Lama Waktu Pemakaian dan Kekentalan Oli pada Mesin Wire Drawing Berbasis Raspberry Pi 1. RESISTOR (ElektRonika KEndali TelekomunikaSI Tenaga LiSTrik KOmputeR), 2(2), 121. https://doi.org/10.24853/resistor.2.2.121-130

Syams, A. M. N., \& Suhartini. (2018). Prototipe Sistem Keamanan Menggunakan Rfid Dan Keypad Pada Ruang Penyimpanan Di Bank Berbasis Arduino Uno. Jurnal Ilmiah Informatika Komputer, 23(2), 144-153. https://doi.org/10.35760/ik.2018.v23i2.2356

Wagyna, A., \& Rahmat. (2019). Jurnal Ilmiah Setrum. 8(1), 134-143.

Wijayanti, C. (2017). Citra Mahasiswa Menggunakan Kendaraan (Studi Fenomenologi Mahasiswa Uns dalam Membangun Citra Menggunkaan Kendaraan Sepeda Motor). Jurnal Analisa Sosiologi, 6(2), 227622. 